\title{
Comparison of Plant Development Rate in Rice Cultivar across Combination of Planting Method and Water Levels
}

\author{
J. Pradhan ${ }^{1 *}$ and M. Kar ${ }^{2}$ \\ ${ }^{1}$ Department of Botany, Plant Physiology and Biochemistry, \\ College of Basic Sciences and Humanities, Dr. Rajendra Prasad Central Agriculture \\ University, Pusa, Samastipur-848125, India \\ ${ }^{2}$ Department of Plant Physiology, College of Agriculture, Odisha University of Agriculture \\ and Technology; Bhubaneswar-751003, India \\ *Corresponding author
}

\section{A B S T R A C T}

\section{Keywords}

water tension, rice,

leaf appearance

rate, stress

condition, no stress

condition

\section{Article Info}

Accepted:

12 May 2020

Available Online:

10 June 2020
This trail was conducted during rabi 2015 with two known establishment methods i.e. non-puddled transplanted and dry direct-seeded rice. There were three water tensions i.e. - $0 \mathrm{kPa},-10 \mathrm{kPa},-40 \mathrm{kPa}$ and five cultivars i.e. Arize-6129, Arize6444, Lalat, Shahbhagi dhan, US 323. This experiment intended to look at the rate of growth of rice cultivar crosswise over a blend of water levels and established methods. The scrutiny was laid out in a split-split plot design with three replications. The investigation unwraps the information that the treatment i.e. no stress condition $(-0 \mathrm{kPa})$ and $-10 \mathrm{kPa}$ perform better when contrasted with the presentation of stress situation $(-40 \mathrm{kPa})$ regardless of cultivars in the vast majority of the development and formative traits. Physical characters estimated regarding leaf appearance rate was found to diminish altogether if there should arise an occurrence of $-40 \mathrm{kPa}$ when contrasted with -0 and $-10 \mathrm{kPa}$.

\section{Introduction}

The world population keeps on expanding every year by more than $1 \%$, which implies around 75 million extra individuals in one year from now (United Nations, 2011). So to keep away a significant nutritional emergency, food production must increase at a similar yearly pace. Moreover, additional foodstuff must be produced in a situation when limitations for natural resources increase. The majority of human staple food source has been mostly covered by three diverse groups of crop: cereals, legumes, and root/ tuber crop.

Worldwide, three major cereal grains (i.e., rice, wheat, and maize) and other minor grains (i.e. barley, sorghum, oat, rye, millet) provided $56 \%$ of the food energy and $50 \%$ of 
the protein consumed on earth (1). Rice (Oryza sativa L.) is one of the leading food crops in the world, a granule of living for 3 billion people, and the staple food for the world's compactly inhabited regions, which contributes $35-60 \%$ of their dietetic calorie intake (2). Globe wide, rice is grown in an area of $160 \mathrm{~m}$ ha with a production of 475.5 million MT (World Rice Acreage, 2015) out of which $90 \%$ of the world's rice is produced and consumed in Asia.

In India it is cultivated around the year in one or the other part of the country in various ecologies spread over $43.7 \mathrm{~m}$ ha with a production of $107.24 \mathrm{~m} \mathrm{t}$, according to the International Grains Council representing the largest area and second-largest production in the world. In Odisha "rice" is synonymous with "food"; furthermore "agriculture", to a considerable extent means growing rice. In the 1950s Odisha was a leading riceproducing state in the country and used to supply a sizeable amount of rice gain to the central pool of food-stock. But the situation was very much reversed in the post-High Yielding Variety(HYV) period. Odisha's share in the country's rice production was more than $10 \%$ in the pre-HYV period while in 1992-93 it came down to $7 \%$.

In Odisha, the widespread and general practice of the establishment of rice is manual transplanting of seedlings with 14-20 days old within the puddled field and otherwise broadcasting of the seeds in the prepared i.e. well tilth field generally known as beushening. Puddling is achieved by rehashed intensive tillage under ponded-water conditions, which helps in reducing the loss of water through percolation and lessening weed emergence due to water inundation in rice fields. It is expensive, burdensome, and lengthy, puddling brings about degradation of soil physical and chemical properties and deprivation of other natural resources. But the yield potential of this tradition is very poor. Irrigated lowland rice systems produce $\sim 75 \%$ of global rice (2). Delivering high return under irrigated systems requires an enormous amount of water (3). It is assessed that to produce $1 \mathrm{~kg}$ of rice grain, $2500 \mathrm{~L}$ of water is required (3). Globally this equates to $33 \%$ of the world's available freshwater being utilized for rice irrigation (3). Within Asia, it is noteworthy for the reason that, approximately half of freshwater being used for rice irrigation (4). With global rice production increment by $70 \%$ by 2030 to feed an evergrowing world population, demands on freshwater for irrigation of rice will just increase unless water management techniques that reduce water use are developed and implemented. These water management techniques, while decreasing total water loss, ought to keep up the yield.

Drought is a meteorological term in an event of protracted shortage in the water supply, whether atmospheric (belowaverage precipitation), surface water, or groundwater. Not simply the lack of water that lowers yield potential, but also the timing and duration of drought stress relates to phenological processes. (5).

Rice has originated from a semi-aquatic ancestor and thus has a better adaptation to semi-aquatic environments than to aerobic conditions (6). Therefore rice is sensitive to moisture stress and because of the water scarcity in the coming years, it is imperative to evaluate the performance of rice cultivar under moisture deficit. Sogginess stress habitually happens, either at least one phonological phases of upland rice crop rose under rainfed condition. The low efficiency in India is chiefly because of its development under rainfed circumstances in the majority of the rice-growing zones. About $62 \%$ of the cropped area is dependent on monsoon rainfall. 
As reported by Singh et al., in 2009 in the Indian scenario, there is around a $45 \%$ decrease in the production of rice due to drought. India is a country of farmers, as agriculture provides livelihood to almost $3 / 4^{\text {th }}$ of the Indian population. The contribution of the agriculture sector to GDP is $17 \%$. But unfortunately it has decreased substantially since the independence. Plant growth and productivity are adversely affected by water stress (i.e. both flood and drought).

The impact of severe drought on GDP has remained $2-5 \%$, which is again a significant issue. Given climate change, it is important to assess the impact of climate extremes on agriculture. From the meteorological history of Odisha, it is discovered that the state is getting around $1451.2 \mathrm{~mm}$ precipitation in around 69.31 rainy days (India Meteorological Dept., Pune)almost consistent year and the most influenced is the rice crop, attributable to its prerequisite of wetland biological system as a rule.

The major challenge in this scenario is to improve the use efficiency of the crop with less water, labor, and chemicals thereby ensuring long term sustainability. Direct Seeded Rice (DSR) is such a method of sowing rice seeds directly into the soil, without going for transplanting as it is less water consumption. It is suitable in reducing labor and water consumption as compared to traditional methods of transplanting.

The above literature is creating a hypothesis that the availability of water lesser than requirement can cause a yield loss. The current study is concerned with the effect of different water levels and establishment methods on the growth of rice plants having an objective to compare plant development rates in terms of leaf number, dead and alive tiller number searching for possible differences.

\section{Materials and Methods}

This present experiment was conducted in the central farm of Orissa University of Agriculture and Technology, Bhubaneswar during rabi 2015. It is situated at $20.250^{\circ} \mathrm{N}$ and $85.81^{\circ} \mathrm{E}$. The field was having cropping history with rice-rice cropping system during 2013-14.

The experiment was having two kinds of establishment methods. Those are 1. Dry direct-seeded rice (DSR) and 2. Non puddled transplanted rice (NPTR). In the DSR sections of dry seeds, the sowing was done on $8^{\text {th }}$ January 2015 by seed drill. The machine was well efficient to sow the seeds at a depth of 2$3 \mathrm{~cm}$. The spacing between row to row was $20 \mathrm{~cm}$. Lifesaving irrigation was given on the next day by sprinkling. Initial operations such as thinning and gap-filling were done 7 days after the sowing of seeds.

For transplanting polythene mat nursery was prepared with a width of $1 \mathrm{~m}$ and a height of $15 \mathrm{~cm}$ of nursery bed. The seeds were soaked overnight and then covered by gunny bags for maintenance of temperature and trouble-free germination. Then the seeds were broadcasted over the nursery bed on $8^{\text {th }}$ January 2015 and covered with straw. After ensuring complete emergence the straw was removed. Healthy rice seedlings were selected from the nursery bed and transplanted on $25^{\text {th }}$ of January, 2015 with the spacing of $22 \mathrm{~cm} \mathrm{x} 14 \mathrm{~cm}$ in nonpuddled condition. Two seedlings were placed per hill during transplanting. Here we kept the date of sowing the same in both the established methods to nullify the effect of age gap of seedlings. The experiment was laid out in Split-split plot Design with three replications having main plot consisting two establishment methods (i.e. DSR and NPTR), subplot having three water levels (i.e. $-0 \mathrm{kPa}$, $10 \mathrm{kPa} \&-40 \mathrm{kPa}$ ) and sub- subplot representing five rice cultivars (i.e. Lalat, 
Sahbhagidhan, US-323, Arize-6129 \& Arize6444). Once the crop is established (around 30 DAS), the stress was imposed by withholding irrigation. In -0kPa (no stress) plots $5 \mathrm{~cm}$ standing water was always maintained. In the case of -10 and $-40 \mathrm{kPa}$ plots irrigation was given based on the tensiometer readings.

\section{Leaf appearance rate}

Leaving the border rows five plants from 5 consecutive hills will be identified (marked with marker sticks) and each of the leaf from their main tiller weekly marked with their respective leaf rank. The number of appeared and ligulated leaves will be weekly recorded. Then graphs were plotted against sum of temperature (sumt).

$\operatorname{Sumt}\left({ }^{0} \mathrm{~cd}\right)=\Sigma_{\text {days }}$ \{mean of daily temperaturebase temperature $\}$

For tropical rice base temperature $=12^{\circ} \mathrm{c}$

\section{Results and Discussion}

Various morpho-physiological characters recorded during the ontogeny of rice crops were analyzed and presented under the following heads and subheads.

\section{Number of appeared leaves}

Fig.1.1 is a graph of the number of appeared leaves as a function of sumt. We can observe there that, initially up to $4^{\text {th }}$ week following establishment number of appeared leaf was higher in DSR than NPTR. However after that it was found higher in NPTR. Among the three water tensions $-10 \mathrm{kPa}$ was recorded higher in afterward stage but they were at par before. At the preliminary stage the highest number was found in US 323 among the 5 varieties. But after $2^{\text {nd }}$ week of establishment cultivar Arize-6444 was found to have a higher number. In the $7^{\text {th }}$ week Arize-6129 in -10kPa NPTR was recorded highest, followed by Arize-6444. Shahbhagi dhan had the lowest number throughout the season.

\section{Live tiller}

From the fig.1.2. it can be markedly observed that till the $4^{\text {th }}$ week after establishment the number of live tillers was higher in DSR than in NPTR. But after that the number was higher in NPTR then DSR. Up to $5^{\text {th }}$ week, the number of live tillers was at par in all the 3 water levels. But later the highest number was found in $-10 \mathrm{kPa}$, then in $-40 \mathrm{kPa}$ followed by - $0 \mathrm{kPa}$. In Arize-6444 the number was highest (18) and in Sahbhagi dhan it was lowest (10) during the whole season.

\section{Dead tiller}

In fig.1.3. it can be seen that initially the number of dead tillers was higher in DSR, but gradually it was found higher in NPTR. In $40 \mathrm{kPa}$ there was more dead tiller than $-10 \mathrm{kPa}$ followed by $-0 \mathrm{kPa}$. But after the $6^{\text {th }}$ week the number of tillers was increased in $-10 \mathrm{kPa}$ as compared to- $40 \mathrm{kPa}$ followed by $-0 \mathrm{kPa}$. In Arize-6444 it was highest (4) and in Shabhagi dhan it was lowest (2).

\section{Discussion}

The photosynthetically active leaf area is a vital parameter for individual plants and depends on the number and size of active leaves. Leaf appearance and expansion increase the active leaf area, while senescence decreases it $(7,8,9)$. It has been that the plasticity of the final rosette leaf area under water deficit in Arabidopsis was mainly a result of plasticity in the area of individual leaves, whereas leaf number was only faintly affected. In many other crop species, leaf number is less affected than leaf expansion by water deficit (10). Thus, processes involved in 
overall leaf production and expansion are uncoupled to some extent. A lesser number of young leaves may be produced under drought or senescence may commence before older leaves. Often senescence in such leaves is typical and characterized by a partial degradation of chlorophylls and proteins and by a reduced nitrogen remobilization.

Drought affects phloem transport and the nitrogen status of leaves, since the source/sink network is altered $(11,12)$. Particularly decreased sink strength in young leaves and reproductive parts participate in these changes. Besides the commencement and the rate of leaf senescence, mechanisms involved in the catabolism of leaf constituents may be altered under abiotic stress $(13,14,15)$. In general, photosynthetic capacity declines before other cellular functions (e.g. respiration, intermediary metabolism associated with nutrient remobilization) are lost (16).

The rate of leaf appearance is of much significance in the rice plant that determines the morpho-physiological activity of the plant, ultimately having a superior impact on grain yield. In this experiment in NPTR the maximum number of leaf per hill was observed as compared to DSR. Maximum leaf number (12 numbers of leaves) was noticed in non-puddled conditions at $7^{\text {th }}$ weeks after establishment while the other recorded.

Initially DSR was found better or faster in terms of leaf emergence as compared to NPTR, it may be due to the transplanting shock. Seedlings again took up normal growth after the healing from shock (19). Among the treatment combinations, Arize-6129 with at $7^{\text {th }}$ week in $10 \mathrm{kPa}$ NPTR found to have more compared to other varieties. It was the consequence of the establishment method, which lead to the greater production of leaf number.
A similar finding of production of more leaves in transplanted condition was noticed by Clerget et al., (20) in rice under different crop establishment. The lower generation of leaf number in direct-seeded rice was basically because of the environmental impact on developmental traits and rates of leaf emergence. This alteration was in charge of ward architectural traits. The kinetics of apical leaf inception was distorted.

Thus, there was an inflection point occurred after with particular to leaf number. Lower number was observed in Sahbhagidhan at the $7^{\text {th }}$ week after establishment. The unsaturated soil condition may likewise be one of the reasons for the lower production of leaves in the case of direct-seeded rice.

In the case of senescent leaf number, higher senescence was observed in NPTR compared to that of DSR. Since the leaf production rate of transplanted rice was more, competitively this indicated that the senescence of leaf was also higher. Rapid senescence of lower leaves were positively associated with grain yield increase in rice (21). The senescence was closely related to the cytokinin concentration under anaerobic conditions.

Leaf senescence at the late development phase of rice lead to loss of photosynthetic competence and had a noteworthy effect on grain filling. The postponed leaf senescence in direct-seeded rice was because of the delayed leaf activity (22). Deciduous trees exposed to severe drought may shed the leaves in summer and produce new leaves several weeks later when the water status of the trees unimproved (17). Since these newly formed leaves are shed again in fall, the investment in these leaves is not paid back by photosynthetic activity and will finally weaken the trees. It might be helpful to consider such responses to drought for genotype selection or breeding. 


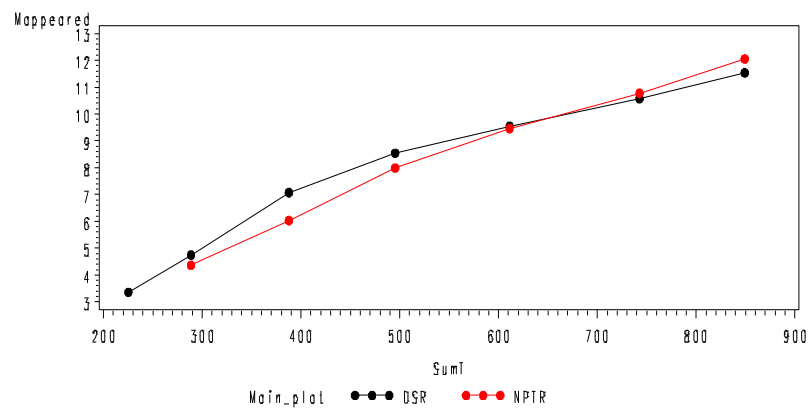

(a)

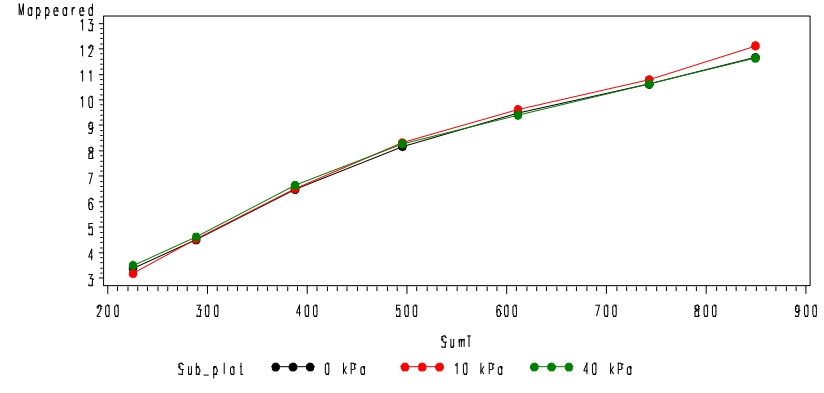

(b)

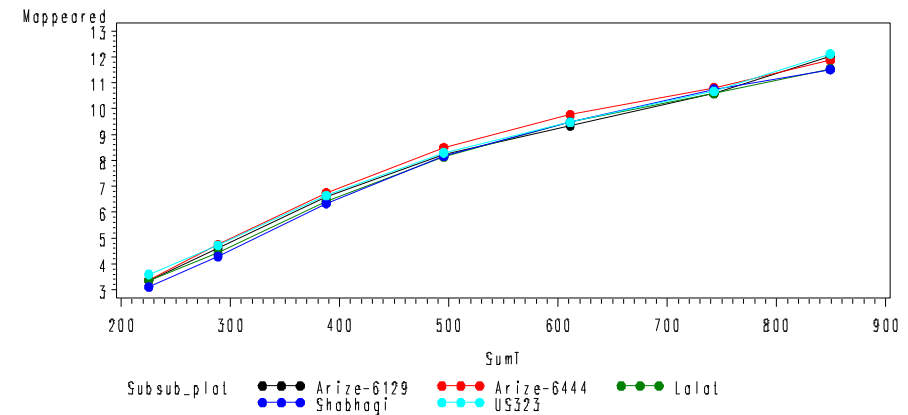

(c)

Fig.1 Effect of establishment methods(a), water tensions(b) and cultivars(c) on leaf appearance rate

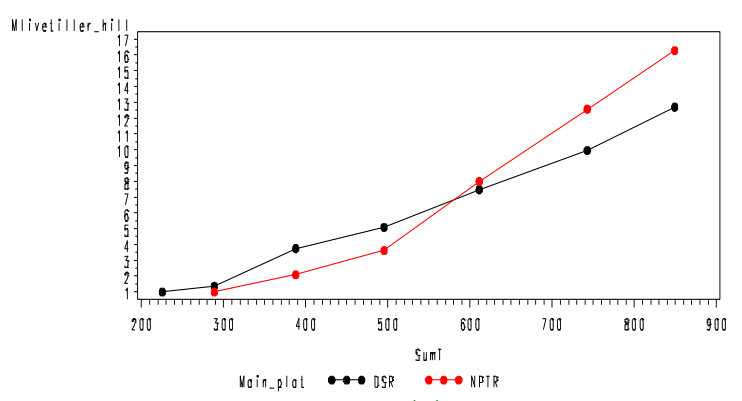

(a)

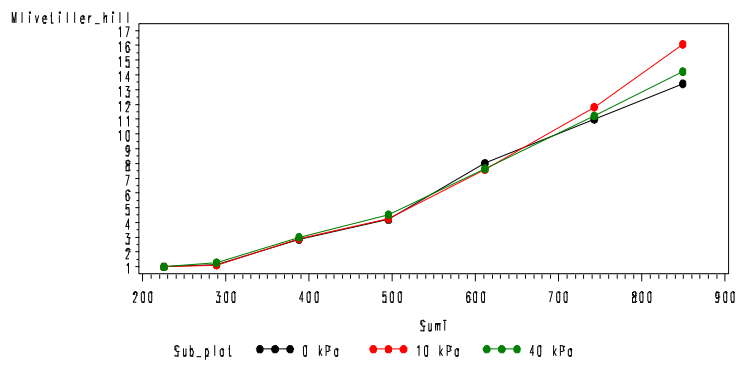

(b)

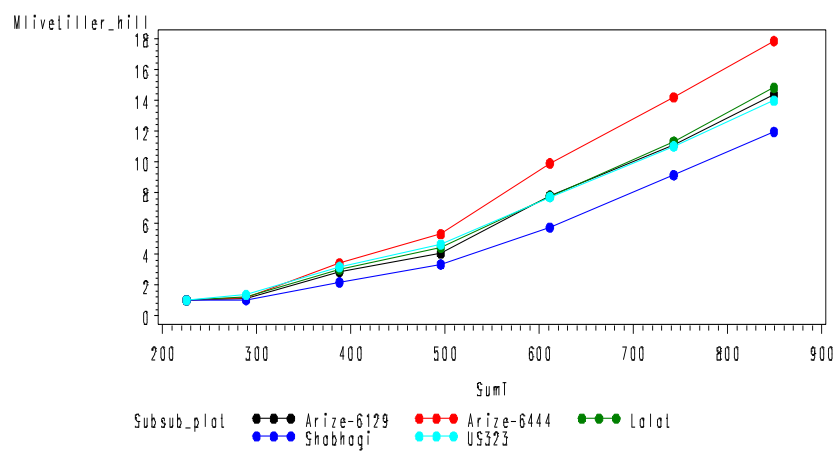

(c)

Fig.2 Effect of establishment methods (a), water tensions(b) and cultivars(c) on number of live tiller 


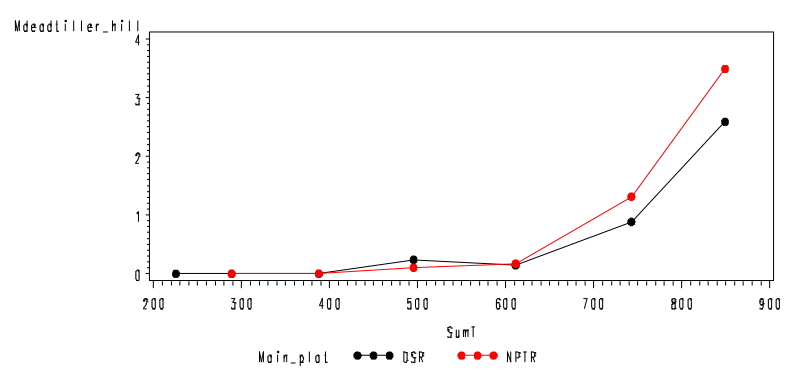

(a)

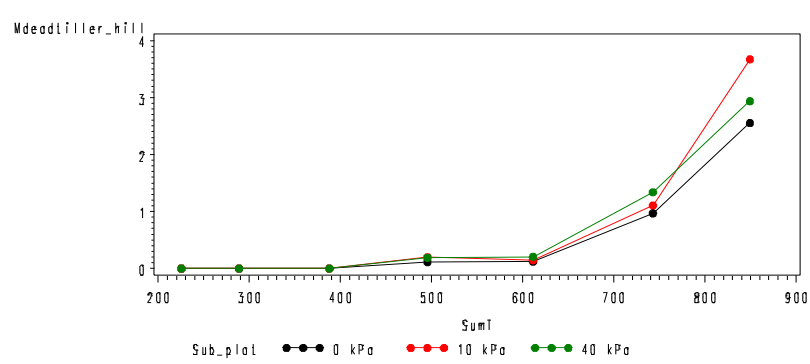

(b)

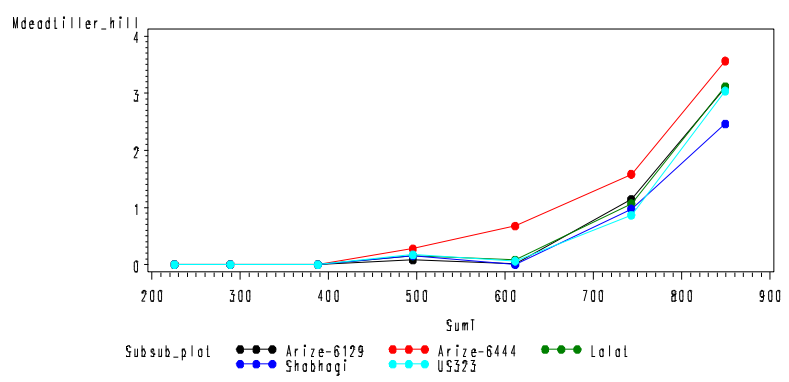

(c)

Fig.3 Effect of establishment methods (a), water tensions (b) and cultivars (c) on number of dead tiller

Young leaves may again be produced more rapidly during a recovery phase following the drought period (7). In this case the drought effects are irreversible on the level of already senesced leaves, but are partially reversible on the level of the whole plant (loss of mature leaves and production of new leaves). Lately emerging leaves may be located differently in previously stressed plants than in unstressed or control plants. Generally new leaves are produced from axillary buds in previously stressed dicotyledonous plants, but not at the shoot apex as in control plants. Even closely related species (e.g. the two forage grasses Digitalis glomerata with pronounced senescence in older leaves and Lolium perenne with marked effects on leaf expansion) may differ in their senescence and leaf expansion patterns under the same drought conditions (7). Although new leaves are formed after a stress period, canopy architecture is affected and overall shoot biomass is decreased $(7,18)$.
Drought stress reduces the tiller number per plant in all rice genotypes. Tiller count of rice differed significantly after the $7^{\text {th }}$ week of establishment among different planting method, significantly higher tiller count was recorded in non-puddled transplanted rice compared to that of direct-seeded rice. The tiller count reduced at the harvest period since all the tillers were not productive which conformed.

The leaf emergence was higher in directseeded crops irrespective of water tension and cultivars up to $5^{\text {th }}$ week as compared to nonpuddled conditions. However after $5^{\text {th }}$-week leaf emergence in non-puddled transplanted rice (NPTR) increased than direct-seeded rice (DSR). It showed that DSR development was delayed down after a certain period and transplanted rice development grabbed. Comparative outcomes were obtained with live and dead tillers. There was the most extreme number of leaf development, 
compelling or effective tillers and dead tillers found in - $10 \mathrm{kPa}$ than - $0 \mathrm{kPa}$ pursued by $40 \mathrm{kPa}$. In Arize-6444 it was found higher among all cultivars. The study also suggested that long term detailed study should carry out to be aware of interactions of establishment methods and water levels on the consequence of physiological characters vis-à-vis its productivity.

\section{References}

1. Cordain, L., Cereal grains: humanity's double-edged sword, Simopoulos, A.P. (Ed.), Evolutionary Aspects of Nutrition and Health. Diet, Exercise, Genetics and Chronic Disease. Karger, Basel, Switzerland, 1999, pp. 19--73.

2. Fageria, N., K., Yield physiology of rice. Journal of Plant Nutrition, (2007). Vol. 30(6), pp. 843--879.

3. Bouman, B., How much water does rice use. Management, (2009).vol. 69, pp115-133.

4. Kukal, S.S. and Sidhu, A.S., 2004. Percolation losses of water in relation to pre-puddling tillage and puddling intensity in a puddled sandy loam rice (Oryza sativa L.) field. Soil and Tillage Research, vol.78(1), pp.1--8.

5. Liu, J.X., Liao, D.Q., Oane, R., Estenor, L., Yang, X.E., Li, Z.C. and Bennett, J., Genetic variation in the sensitivity of anther dehiscence to drought stress in rice, Field Crops Research, 2006, vol. 97, pp. 87--100.

6. Lafitte, H.R., and Bennett, J., Requirements for aerobic rice: Physiological and molecular considerations. In Water-Wise Rice Production (B. A. M. Bouman, H. Hengsdijk, B. Hardy, P. S. Bindraban, T. P. Tuong, and J. K. Ladha, Eds.), 2002, pp. 259--274. International Rice Research Institute, Los Ban os, Philippines.

7. Blösch, R.M., Riesen, O. and Feller, U.,
Extended drought periods in grasslands: impacts on the number of photosynthetically active leaves and on leaf senescence in grass and clover species, Int. J. Energy Environ., 2015, vol. 9, pp.147--155.

8. Esmaeilzade-Moridani, M., Kamkar, B., Galeshi, S., Ghaderifar, F. and Da Silva, J.A.T., Leaf expansion and transpiration responses of millet species to soil water deficit, Pedosphere, 2015, vol. 25, pp. 834--843.

9. Marquez-Garcia, B., Shaw, D., Cooper, J.W., Karpinska, B., Quain, M.D., Makgopa, E.M., Kunert, K. and Foyer, C.H., Redox markers for drought-induced nodule senescence, a process occurring after drought-induced senescence of the lowest leaves in soybean (Glycine max). Ann. Bot. 2015, vol. 116, pp. 497--510.

10. Wery, J., Differential effects of soil water deficit on the basic plant functions and their significance to analyze crop responses to water deficit in indeterminate plants, Australian Journal of Agricultural Research, 2005, vol. 56, pp. 1201--1209.

11. Borrell, A., Hammer, G., and Van Oosterom, E., Stay-green: a consequence of the balance between supply and demand for nitrogen during grain filling?, Ann. Appl. Biol., 2001, vol. 138, pp. 91-95.

12. Feller, U., Anders, I., and Wei, S., Effects of PEG-induced water deficit in Solanum nigrum on $\mathrm{Zn}$ and $\mathrm{Ni}$ uptake and translocation in split root systems., Plants, 2015, vol. 4, pp.284--297.

13. Thoenen, M., Herrmann, B., and Feller, U., Senescence in wheat leaves: is a cysteine endopeptidase involved in the degradation of the large subunit of Rubisco? Acta Physiol. Plant, 2007, vol. 29, pp. 339--350.

14. Feller, U., Anders, I., and Mae, T., Rubiscolytics: fate of Rubisco after its enzymatic function in a cell is terminated, 
J. Exp. Bot., 2008, vol. 59, pp. 1615-1624.

15. Simova-Stoilova, L., Vaseva, I., Grigorova, B., Demirevska, K., and Feller, U., Proteolytic activity and cysteine protease expression in wheat leaves under severe soil drought and recovery, Plant Physiol. Biochem., 2010, vol. 48, pp. 200--206.

16. Hörtensteiner, S. and Feller, U., Nitrogen metabolism and remobilization during senescence, J. Exp. Bot., 2002, vol.53, pp. 927--937.

17. Haldimann, P., Gallé, A. and Feller, U., Impact of an exceptionally hot dry summer on photosynthetic traits in oak (Quercus pubescens) leaves, Tree Physiol., 2008, vol. 28, pp.785--795.

18. Gilgen, A.K., Signarbieux, C., Feller, U. and Buchmann, N., Competitive advantage of Rumex obtusifolius L: might increase in intensively managed temperate grasslands under drier climate, Agric. Ecosyst. Environ., 2010, vol.135, pp.15--
23.

19. Salam, M., U., Jones, J., W. and Kobayashi, K., Predicting nursery growth and transplanting shock in rice. Experimental Agriculture, 2001, vol. 37(1), pp. 65--81.

20. Clerget, B., Crisanta, B., James, R., Teodoro, Q., Correa, H. and Joseph, S., Modifications in development and growth of a dual-adapted tropical rice variety grown as either a flooded or an aerobic crop, Field Crops Res., 2014, vol. 155, pp. 134--143.

21. Park, J.H., and Lee, B.W., Photosynthetic characteristics of rice cultivars with depending on leaf senescence during grain filling, Korean, J. Crop Sci., 2003, vol. 48, pp. 216--223.

22. Wang, H., Bouman, B.A.M., Zaho, D., Wang, C. and Moya, P.F., Aerobic rice in Nothern China: opportunities and challenges in water wise rice production, IRRI, Los Banos the Philipines, 2002, pp. 143--154.

\section{How to cite this article:}

Pradhan. J. and Kar. M. 2020. Comparison of Plant Development Rate in Rice Cultivar across Combination of Planting Method and Water Levels. Int.J.Curr.Microbiol.App.Sci. 9(06): 3947. doi: https://doi.org/10.20546/ijcmas.2020.906.005 